\title{
Uczelnia jako partner dla władz samorządowych i otoczenia gospodarczego $\mathrm{w}$ regionie
}

\section{The university as a partner for local authorities and the economic environment in the region}

\begin{abstract}
Streszczenie
Publikacja w syntetyczny sposób przedstawia historię Wydziału Architektury Politechniki Krakowskiej. Autor prezentuje strukturę organizacyjną Wydziału, definiującą kierunki naukowej działalności kadry akademickiej. Omówione przez Autora osiągnięcia naukowe i dydaktyczne Wydziału Architektury, ocenianego przez zewnętrzne instytucje i organizacje uprawnione do udzielania akredytacji, dają informacje przydatne we wzajemnych kontaktach z partnerami współpracy naukowej, dydaktycznej i twórczej.
\end{abstract}

Słowa kluczowe: uczelnia, struktura organizacyjna, kadra akademicka, potencjał naukowy i twórczy

\section{Abstract}

Paper presents the history of the Faculty of Architecture of the Cracow University of Technology in a synthetic way. The author presents the organizational structure of the Faculty, that defines the directions of research activity of the academic staff. The didactic and research achievements of the Faculty staff, presented by the author, assessed by external institutions and organizations authorized to grant accreditation, give information useful for possible partners of the future scientific, educational and creative cooperation.

Keywords: the University, organizational structure, academic staff, scientific potential and creative 


\section{WSTĘP}

Wydział Architektury jest częścią Politechniki Krakowskiej - akademickiej publicznej szkoły wyższej o przeszło 70-letniej tradycji w kształceniu architektów. Krakowski Wydział Architektury zajmuje od wielu lat wysoką pozycję naukową w polskim środowisku akademickim, potwierdzaną przez kolejne procedury parametryzacyjne kategorią „ $A$ ”. Wydział Architektury posiada pełne prawa akademickie - do przeprowadzania przewodów doktorskich i habilitacyjnych oraz postępowania do tytułu naukowego profesora - jako jedna z czterech w Polsce uczelni technicznych kształcących architektów ${ }^{1}$. Te uprawnienia zapewnia Wydziałowi wysoko wykwalifikowana kadra naukowa licząca 195 osób, w skład której wchodzi 56 samodzielnych pracowników nauki, w tym 19 z tytułem naukowym profesora oraz 95 pracowników ze stopniem naukowym doktora. Kadra nauczycieli akademickich - uczących i prowadzących badania naukowe - wykorzystuje w procesie dydaktycznym wciąż pogłębianą i aktualizowaną wiedzę, związaną z prowadzonymi badaniami naukowymi oraz doświadczeniami z działalności twórczej i praktyki zawodowej. Siła uczelni zasadza się na kompleksowym i zintegrowanym nauczaniu architektury i urbanistyki, prowadzonym na wysokim poziomie przez kadrę nauczającą, w tym również przez praktyków o międzynarodowej renomie.

Obecnie Wydział kształci studentów na trzech kierunkach studiów o profilu ogólnoakademickim, na studiach I stopnia - inżynierskich i II stopnia - magisterskich. Do zawodu architekta - przyszłych architektów i urbanistów - studenci kształcą się na kierunku architektura. Studenci zagraniczni i polscy na kierunku studiów architektura mogą kształcić się od 2013 roku na studiach II stopnia w języku angielskim. W 2017 roku uruchomiona została dla studentów polskich i zagranicznych możliwość podjęcia studiów w języku angielskim również na I stopniu studiów. Specjalistów do zawodu architekta krajobrazu kształcimy od 2002 roku na kierunku studiów architektura krajobrazu. W ramach rozszerzania oferty dydaktycznej Wydział Architektury w roku akademickim 2016/2017 rozpoczął kształcenie specjalistów z zakresu gospodarki przestrzennej na międzywydziałowych studiach II stopnia w specjalności urbanistyka i transport - wspólnie z Wydziałem Inżynierii Lądowej oraz planowanie przestrzenne i gospodarka komunalna - wspólnie z Wydziałem Inżynierii Środowiska. Wydział Architektury Politechniki Krakowskiej prowadzi studia III stopnia - doktoranckie - w ramach dyscypliny naukowej architektura i urbanistyka. Realizując założenia filozofii permanentnego kształcenia, Wydział Architektury prowadzi studia podyplomowe (w ośmiu specjalnościach), pozwalające ich absolwentom na rozszerzenie wiedzy specjalistycznej i dostosowanie kwalifikacji do zmieniających się potrzeb rynku pracy.

Cele statutowe Wydziału Architektury Politechniki Krakowskiej jednoznacznie zdefiniowane są w dokumencie Misja Wydziału Architektury:

Wydział Architektury Politechniki Krakowskiej oferuje swoim studentom możliwość osiągnięcia najwyższego poziomu wiedzy, umiejętności i kreatywności w kształtowaniu przestrzeni. Celem szkoły jest przygotowanie wysokiej klasy specjalistów do wykonywania zawodu zaufania społecznego, 
rozumiejących znaczenie wartości kulturowych w globalizującym się świecie, otwartych na permanentne poszerzanie swojej wiedzy i umiejętności praktycznych, kierujących się uniwersalnymi zasadami etyki w realizacji potrzeb jednostek i grup społecznych. Celem szkoły jest również wspieranie rozwoju kadry naukowej w zakresie dyscypliny architektura i urbanistyka².

Wydział Architektury Politechniki Krakowskiej prowadzi szeroką współpracę i wymianę dydaktyczną i naukową z wieloma krajowymi i zagranicznymi ośrodkami akademickimi, współpracę z samorządami terytorialnymi i otoczeniem gospodarczym oraz profesjonalnymi organizacjami architektonicznymi w kraju i zagranicą. Pracownicy, absolwenci i studenci Wydziału Architektury osiągają sukcesy zawodowe, potwierdzone nagrodami uzyskiwanymi w konkursach krajowych i zagranicznych oraz wysoko ocenianymi przez środowisko zawodowe i społeczeństwo realizacjami obiektów architektonicznych i zespołów urbanistycznych i krajobrazowych, co jest efektem wiedzy uzyskanej na Wydziale Architektury.

Wydział Architektury powstał w ramach Wydziałów Politechnicznych Akademii Górniczej z siedzibą na Wawelu już w pierwszych dniach wolności po II wojnie światowej - pierwszy egzamin na studia odbył się na dziedzińcu wawelskim w maju 1945 roku. Wydziały Politechniczne Akademii Górniczej zostały przekształcone dekretem rządowym w 1954 roku w Politechnikę Krakowską:

§ 1. Mając na uwadze wielki rozwój budownictwa przemysłowego, wodnego i lądowego w regionie krakowskim, w szczególności powstanie nowych potężnych obiektów, jak Nowa Huta, Jaworzno i Oświęcim, a nadto potrzeby rolnictwa i wsi, celem zabezpieczenia wykonania planów gospodarczych okręgu krakowskiego przez zapewnienie stałego dopływu wykwalifikowanych kadr inżynierskich dla istniejących i nowobudujacych się obiektów - tworzy się Politechnikę Krakowską.

$\S 2$. Pracownicy nauki, inni pracownicy nauczający oraz pomocniczy personel techniczny, zatrudnieni na wydziałach: Architektury, Budownictwa Lądowego, Budownictwa Wodnego, Mechanicznym Akademii Górniczo-Hutniczej w Krakowie... stają się pracownikami Politechniki Krakowskiej³.

Te leżące u podstaw powołania Politechniki Krakowskiej założenia służebności wobec regionu i gospodarki - przez kształcenie wykwalifikowanych kadr inżynierskich, zapewniających realizację planów i zamierzeń gospodarczych regionu krakowskiego i kraju - są wciąż aktualne i wpisane we współczesną „Misję i Strategię” Wydziału Architektury.

\section{MISJA WYDZIAŁU ARCHITEKTURY JEST SPÓJNA Z MISJĄ UCZELNI I POLEGA NA ${ }^{4}$}

- kształceniu wysokokwalifikowanych kadr specjalistów w zakresie architektury i urbanistyki, architektury krajobrazu i gospodarowania przestrzenią, mogących sprostać wyzwaniom gospodarki krajowej i światowej, działać na rzecz zrównoważonego rozwoju i podnoszenia jakości środowiska życia człowieka; 
- kształceniu kadr naukowych, przez wspomaganie rozwoju ich pasji badawczej oraz uczestnictwo w krajowej i światowej wymianie naukowej;

- rozwijaniu dyscypliny wiedzy i kultury eksperymentu naukowego;

- rozwijaniu kreatywności i innowacyjności w integracji teraźniejszości z przyszłością;

- rozwijaniu twardych i miękkich umiejętności profesjonalnych sprzyjających zawodowej skuteczności;

- kształtowaniu wysokich standardów etyki zawodowej, odpowiedzialności i poszanowania dla praw człowieka - jednostek i grup społecznych oraz w odniesieniu do kształtowanej lub przekształcanej przestrzeni;

- służeniu gospodarce i całemu społeczeństwu poprzez rozwiązywanie problemów technicznych i technologicznych, programowo-przestrzennych i estetycznych, a także społeczno-ekonomicznych oraz wdrażanie wyników badań naukowych do praktyki gospodarczej;

- rozwijaniu międzynarodowej współpracy naukowej i dydaktycznej oraz współpracy z szeroko rozumianym otoczeniem gospodarczym ${ }^{5}$.

Współczesny Wydział Architektury Politechniki Krakowskiej jest szkołą wyższą cieszącą się wysokim uznaniem w Polsce i poza jej granicami. Jest jedyną w Polsce i w bloku wschodnim dawnych krajów demokracji ludowej, posiadającą akredytację (od 2000 roku, wciąż z powodzeniem uzyskiwaną na okresy 5-letnie) dla kierunku studiów architektura (architektura i urbanistyka), przyznawaną przez prestiżową instytucję - Królewski Instytut Architektów Brytyjskich (RIBA - Royal Institute of British Architects), udzielającą akredytacji wielu wyróżniającym się uczelniom kształcącym architektów na całym świecie. Oznacza to, że absolwenci krakowskiego Wydziału Architektury otrzymują dwa dyplomy - polski i angielski.

Krakowski Wydział Architektury wpisany jest również na listę notyfikacyjną Unii Europejskiej - dyplomy absolwentów kierunku architektura naszego Wydziału wraz z dokumentem potwierdzającym przynależność do Izby Architektów uprawniają do wykonywania zawodu architekta w krajach Unii Europejskiej. Wydział posiada również akredytację Komisji Akredytacyjnej Uczelni Technicznych, która ma uprawnienia komisji międzynarodowej, a także akredytacje Polskiej Komisji Akredytacyjnej i Państwowej Komisji Akredytacyjnej. Te akredytacje są potwierdzeniem wysokiego poziomu kształcenia. Kierunek studiów architektura krajobrazu prowadzony jest na Wydziale Architektury Politechniki Krakowskiej od 2002 roku i jako jedyny w Polsce posiada akredytację Europejskiej Federacji Architektury Krajobrazu (EFLA - European Federation for Landscape Architecture - od 2005 roku).

Wydział Architektury prowadzi działalność naukową usytuowaną w obszarze wiedzy nauk technicznych, w dziedzinie nauk technicznych i w dyscyplinie naukowej architektura i urbanistyka. 


\section{STRUKTURA ORGANIZACYJNA WYDZIAtU ARCHITEKTURY}

W strukturze organizacyjnej Wydziału Architektury znajdują się następujące jednostki:

1. Instytut Historii Architektury i Konserwacji Zabytków (A-1) - w skład którego wchodzą:

- Katedra Ochrony Dziedzictwa Kulturowego i Architektury Współczesnej,

- Katedra Historii Architektury, Urbanistyki i Sztuki Powszechnej,

- Zakład Historii Architektury Polskiej.

2. Instytut Projektowania Architektonicznego (A-2) - w skład którego wchodzą:

- Katedra Architektury Miejsc Pracy i Rekreacji - z zespołami:

- Teorii i Estetyki Architektury;

- Architektury Sportu i Rekreacji;

- Architektury Przemysłowej;

- Architektury Współczesnego Regionalizmu,

- Zakład Architektury Użyteczności Publicznej,

- Zakład Architektury Mieszkaniowej i Kompozycji Architektonicznej,

- Zakład Architektury Elementarnej,

- Zakład Architektury Społeczno-Usługowej,

3. Instytut Projektowania Urbanistycznego (A-3) - w skład którego wchodzą:

- Katedra Kompozycji Urbanistycznej,

- Katedra Kształtowania Środowiska Mieszkaniowego,

- Zakład Przestrzeni Urbanistycznych,

- Zakład Kształtowania Przestrzeni Komunikacyjnych,

4. Instytut Projektowania Budowlanego (A-4) - w skład którego wchodzą:

- Katedra Budownictwa Ogólnego i Materiałów Budowlanych,

- Katedra Konstrukcji i Technik Budowlanych - z zespołami:

- Konstrukcji Budowlanych i Technik Budowlanych,

- Zakład Geometrii Wykreślnej, Rysunku Technicznego i Grafiki Inżynierskiej,

5. Instytut Projektowania Miast I Regionów (A-5) - w skład którego wchodzą:

- Katedra Planowania Przestrzennego i Ochrony Środowiska,

- Zakład Odnowy Miast,

- Zakład Projektowania Obszarów Śródmiejskich,

- Zakład Architektury i Planowania Wsi,

6. Zakład Rysunku, Malarstwa i Rzeźby (A-7),

7. Instytut Architektury Krajobrazu (A-8) - w skład którego wchodzą:

- Zakład Krajobrazu Otwartego i Budowli Inżynierskich,

- Zakład Kompozycji i Planowania Krajobrazu,

- Zakład Sztuki Ogrodowej i Terenów Zielonych.

Struktura organizacyjna Wydziału związana jest z szeroką i wielowątkową problematyką kształcenia na trzech poziomach studiów i obejmuje zagadnienia znajdujące się w obszarze 
zainteresowań naukowych pracowników tych jednostek. Dorobek naukowy nauczycieli akademickich - pracowników Wydziału Architektury - publikacje naukowe (artykuły) w recenzowanych fachowych czasopismach, publikacje książkowe, monografie, liczne wystąpienia z referatami na krajowych, międzynarodowych i zagranicznych konferencjach naukowych, naukowe opracowania studialne - w tym granty i opracowania zlecane przez podmioty gospodarcze, a także prace twórcze i liczne, cieszące się uznaniem środowisk fachowych i społeczeństwa realizacje obiektów architektonicznych i zespołów urbanistycznych i krajobrazowych - dają gwarancję wysokiego poziomu aktualnej wiedzy i umiejętności zawodowych, skutecznie przekładających się na jakość kształcenia. Dorobek naukowy, zawodowy i dydaktyczny nauczycieli akademickich i całego Wydziału jako jednostki organizacyjnej jest permanentnie monitorowany przez cyklicznie powtarzające się oceny - ankiety oceny pracowników naukowych, prowadzone przez Uczelnię, oraz w procesie ogólnopolskiej parametryzacji jednostek naukowych, prowadzonej przez Komitet Ewaluacji Jednostek Naukowych co cztery lata w oparciu o akty prawne wyższego rzędu - ustawę sejmową i rozporządzenie Ministra Nauki i Szkolnictwa Wyższego.

Niezależnie od wymienionych wyżej procedur oceny, pracownicy naukowi w trakcie osobistej kariery naukowej podlegają ciągłym procesom oceny przez recenzentów i komisje powoływane przez Uczelnię i Centralną Komisję ds. Stopni i Tytułów Naukowych, aby uzyskać kolejne stopnie - doktora, doktora habilitowanego lub tytuł naukowy profesora. W trakcie tych procedur oceniana jest jakość całego dorobku naukowego, oryginalność osiągnięcia naukowego i jego znaczenie dla rozwoju dyscypliny wiedzy, dorobek dydaktyczny i organizacyjny, a także osiągnięcia w zakresie kształcenia kadr - w przypadku ubiegania się o tytuł naukowy. W karierze naukowej nauczycieli akademickich w dyscyplinie architektura i urbanistyka sprawdzane są i poddawane ocenie zawodowe umiejętności praktyczne - doświadczenie oraz dorobek projektowy i realizacyjny. Wydział wspiera, także finansowo, starania pracowników o uzyskanie uprawnień zawodowych, dzięki czemu Wydział Architektury wyróżnia się w macierzystej Uczelni ponad 40\% udziałem w kadrze nauczającej architektów czynnych zawodowo, posiadających uprawnienia budowlane w zakresie architektury.

\section{WSPÓŁPRACA MIĘDZYNARODOWA ORAZ POTENCJAŁ NAUKOWY I TWÓRCZY KADRY NAUCZAJAZCEJ}

Kadra nauczająca Wydziału Architektury Politechniki Krakowskiej stanowi znaczący w regionie krakowskim i województwie małopolskim potencjał naukowy, zawodowy i twórczy, wykorzystywany w procesie kształcenia studentów na wszystkich kierunkach i poziomach studiów, w pracy badawczej - studialnej i zawodowej - twórczej na rzecz regionu oraz w najintensywniejszej na Uczelni współpracy międzynarodowej. 
Nad studiami w języku angielskim czuwa Pełnomocnik Dziekana ds. Międzynarodowej Współpracy Dydaktycznej i Studiów Anglojęzycznych - dr hab. inż. arch. Anna Franta, prof. PK, a nad programem współpracy międzynarodowej wraz z Koordynatorem ds. Programu Tennessee - dr. hab. inż. arch. Krzysztofem Bojanowskim i Koordynatorem ds. Programu Erasmus - dr inż. arch. Justyną Tarajko-Kowalską w ramach Biura ds. Współpracy Międzynarodowej WA PK.

Prowadzona przez Wydział Architektury wymiana dydaktyczna obejmuje największą ilość studentów w skali macierzystej Uczelni.

W studiach częściowych w ramach 70 umów bilateralnych z uczelniami europejskimi w Programie LLP Erasmus i CEEPUS bierze udział około 200 studentów rocznie (w tym około 100 wyjeżdżających i 100 przyjeżdżających). W wymianach realizowanych w ramach innych umów międzynarodowych (m.in. z USA, Australią, Meksykiem, Chinami, Koreą Południową, Tajwanem i Singapurem) uczestniczy corocznie ponad 50 studentów (w tym około 35 przyjeżdżających i 15 wyjeżdżających). Najdłużej realizowaną współpracą i wymianą dydaktyczną jest aktywnie funkcjonujący od 25 lat program bilateralnej wymiany studenckiej pomiędzy WA PK a College of Architecture \& Planning University of Tennessee (obecnie College of Architecture \& Design), plasującym się od lat wśród 10 najlepszych publicznych uczelni architektury w Stanach Zjednoczonych. Jest to najdłużej systematycznie funkcjonujący program semestralnej wymiany, jaki jest oferowany studentom architektury w USA i w Polsce, a świadectwem jego efektywności i popularności jest liczba niemal 600 studentów obu uczelni, którzy w ciągu 25 lat prowadzenia wymiany byli jej uczestnikami.

Istotną dla studentów konsekwencją udziału w studiach częściowych jest również możliwość wykonywania prac dyplomowych z podwójnym promotorstwem (promotor z WA PK i współpromotor z uczelni partnerskiej lub odwrotnie - realizowana m.in. z HTW Dresden, FH Münster, Universita degli Studi di Firenze, Bauhaus Universitat Weimar, TU Berlin, Politecnico di Torino, Politecnico di Milano) oraz możliwość uzyskania podwójnego dyplomu WA PK i wybranych uczelni partnerskich (na podstawie podpisanej umowy o podwójnym dyplomowaniu m.in. z Münster, Hildesheim, Cottbus) ${ }^{6}$.

Oprócz współpracy z wymienionymi wyżej oraz wieloma innymi uczelniami europejskimi - m.in. Esquela Téchnica Superior de la Architectura de Madrid, Faculty of Architecture Polytechnic University in Turin, Barcelona School of Architecture ETSAB Polytechnic University of Catalunya UPC - Wydział Architektury rozszerza współpracę z kilkoma uczelniami z Chin School of Architecture and Urban Planning Huazhong University of Science and Technology Wuhan oraz Guangdong University of Technology. Wydział Architektury PK rozpoczyna także współpracę z Tianjin Chengjian University w ramach wspólnego przedsięwzięcia - Chińsko-Polskiej Szkoły Inżynierii po podpisaniu umowy w MNiSW.

Profesorowie Wydziału Architektury Politechniki Krakowskiej gościli z licznymi wykładami w wielu zagranicznych uczelniach współpracujących z naszym Wydziałem. Jednocześnie w ostatnich 12 latach kilkudziesięciu wykładowców wygłosiło wykłady gościnnie na WA PK, a wielu z nich przebywało na Wydziale dłużej w charakterze profesorów wizytujących.

Wydział Architektury monitoruje efekty kształcenia, korzystając z opinii komisji akredytacyjnych, z badań ankietowych prowadzonych przez Biuro Karier Politechniki Krakowskiej 
oraz z opinii działającej przy WA PK Rady Pracodawców, opinii egzaminatorów zewnętrznych - architektów praktyków z Izby Architektów, uczestniczących w obronach dyplomów inżynierskich i magisterskich oraz bezpośredniej współpracy z regionalnym samorządem zawodowym - Małopolską Okręgową Izbą Architektów. Konieczność ciągłego dostosowywania procesu nauczania do potrzeb rynku pracy wiąże się bezpośrednio z intensyfikacją współpracy z otoczeniem samorządowym i biznesowym Małopolski i zinstytucjonalizowaniem tych kontaktów przez powołanie Pełnomocnika Dziekana WA ds. Współpracy z Władzami Samorządowymi i Otoczeniem Gospodarczym w Kraju i Zagranicą - tę funkcję pełni dr hab. inż. arch. Krystyna Paprzyca. Dzięki zrozumieniu tego problemu ze strony władz samorządowych i przedstawicieli prywatnego sektora gospodarki oraz dostrzeżeniu obustronnego interesu - tak pośredniego, przez związanie kształcenia studentów z realiami rynku, jak i bezpośredniego, przez możliwość uzyskiwania wielowariantowych opracowań studialnych kursowych i dyplomowych, opracowywanych przez studentów i doktorantów pod opieką prowadzących zajęcia pracowników naukowych WA PK - podpisano w ostatnich kilku latach liczne umowy o współpracy i zrealizowano wiele przydatnych dla partnerów umów opracowań studialnych.

Wydział przez realizację w ramach procesu dydaktycznego zadań związanych z oczekiwaniami i potrzebami otoczenia samorządowego i gospodarczego dąży do przygotowania swoich absolwentów do praktyki zawodowej i zmieniających się wymagań rynku pracy. Służy temu szeroka wiedza i umiejętności nabywane w trakcie studiów, przydatne w podejmowaniu decyzji projektowych w różnych skalach, związanych z kształtowaniem przestrzeni - od planowania przestrzennego i projektowania urbanistycznego do obiektów i detali architektonicznych oraz elementów wyposażenia. Nasi absolwenci kształcą i rozwijają umiejętności pracy badawczej w ramach obligatoryjnego i fakultatywnego programu studiów, a także przez pracę w studenckim ruchu naukowym, uczestnictwo w warsztatach projektowych czy współpracę przy tematach badawczych realizowanych w jednostkach Wydziału.

Nauczyciele akademiccy - pracownicy naukowi Wydziału Architektury w ramach działalności statutowej, grantów, opracowań studialnych zleconych przez instytucje zewnętrzne prowadzą badania obejmujące szeroki wachlarz problemów i zagadnień, mieszczących się w profilu strategii badawczej jednostek Wydziału Architektury Politechniki Krakowskiej. Wykorzystując wiedzę uzyskaną i rozwijaną przez badania naukowe i działalność dydaktyczną - integralnie związane z osobistą twórczą działalnością zawodową - projektują i realizują obiekty architektoniczne, zespoły urbanistyczne i krajobrazowe, które budują wysoką markę Wydziału Architektury i macierzystej Uczelni. Z pewnością potwierdzają one przekonanie, że Wydział Architektury Politechniki Krakowskiej jest dobrym partnerem do współpracy z otoczeniem samorządowym i gospodarczym regionu. 


\section{PRZYKŁADOWE PRACE TWÓRCZE - WYBRANE REALIZACJE PRACOWNIKÓW NAUKOWYCH WYDZIAtU ARCHITEKTURY POLITECHNIKI KRAKOWSKIEJ}

1. Podziemne Muzeum Rynku Głównego w Krakowie (il. 1-2): projekt architektoniczny - prof. dr hab. inż. arch. Andrzej Kadłuczka (Wydział Architektury Politechniki Krakowskiej); projekt plastyczny scenariusza ekspozycji: Mieczysław Bielawski, Marcin Pietuch, Tomasz Salwierz; opracowanie merytoryczne scenariusza: Cezary Buśko, Sławomir Dryja, Wojciech Głowa, Stanisław Sławiński; technologia i multimedia: Agata Sitko i Tomasz Zalewski z zespołem TRIAS (fot. Piotr Kotucha).

„...Zejście do podziemi Rynku Krakowskiego jest... psychologicznym aktem teleportacji do przeszłości..."7.

Realizacja unikalnego w skali międzynarodowej parku archeologicznego - Podziemnego Muzeum Rynku Głównego w Krakowie, oddanego do użytku 24 września 2010 roku, autorstwa lidera „krakowskiej szkoły konserwacji zabytków” - prof. dr. hab. inż. arch. Andrzeja Kadłuczki, jest wybitnym osiągnięciem naukowym i twórczym, które niewątpliwie jest najwyższej klasy „marką” Politechniki Krakowskiej. Jest to osiągnięcie twórcze, które nie ma sobie równych w Polsce i jest wysoko oceniane na arenie międzynarodowej. To osiągnięcie, charakteryzujące się wyjątkowo silnymi związkami między wiedzą wynikającą z wieloletnich badań i doświadczeń naukowych a twórczością, uzyskało także najwyższą możliwą ocenę w procesie ewaluacji jednostki.

2. Rewaloryzacja Zamku Krzyżackiego w Gniewie (il. 3-5): prace konserwatorskie i adaptacyjne $^{8}$; autorzy: krakowska firma ARCHECON - prof. dr hab. inż. arch. Andrzej Kadłuczka, dr inż. arch. Dominik Przygodzki (Wydział Architektury Politechniki Krakowskiej); projekt i realizacja 2010-2013 (fot. J. Gyurkovich).

3. Muzeum Narodowe Ziemi Przemyskiej (il. 6-7): pl. Berka Joselewicza 1, 37-700 Przemyśl; autorzy: KKM Kozień Architekci, dr inż. arch. Marek Kozień, dr inż. arch. Magdalena Kozień-Woźniak (Wydział Architektury Politechniki Krakowskiej), mgr inż. arch. Katarzyna Kozień-Kornecka (fot. archiwum KKM Kozień Architekci).

4. Galeria Sztuki Współczesnej przy MCK „Sokół” w Nowym Sączu (il. 8-9): autorzy: KKM Kozień Architekci, dr inż. arch. Marek Kozień, dr inż. arch. Magdalena Kozień-Woźniak (Wydział Architektury Politechniki Krakowskiej), mgr inż. arch. Katarzyna Kozień-Kornecka (fot. Jacek Gyurkovich).

5. Łęki Górne - kościół pw. Chrystusa Króla (il. 10-14): projekt i realizacja: 1997-2007; autorzy: architektura (il. 10 i 14) - prof. dr hab. inż. arch. Jacek Gyurkovich, prof. dr hab. inż. arch. Ewa Węcławowicz-Gyurkovich, dr hab. inż. arch. Mateusz Gyurkovich; konstrukcja: dr inż. Leszek Zapał; wystrój wnętrza, meble - prof. dr hab. inż. arch. Jacek Gyurkovich, prof. dr hab. inż. arch. Ewa Węcławowicz-Gyurkovich; witraże (il. 12 - Krzew Gorejący; il. 13 - Golgota): prof. dr hab. inż. arch. Ewa Węcławowicz-Gyurkovich; rzeźby - figura 
Chrystusa Króla (il. 11), droga krzyżowa - dr hab. art. rzeźbiarz Józef Wąsacz (wszyscy autorzy: Wydział Architektury Politechniki Krakowskiej) (fot. Jacek Gyurkovich).

Autorzy architektury przyjęli założenie, że istniejący w pobliżu...

zabytkowy kościółek, który po czterystu latach funkcjonowania i dokonywanych w tym okresie wielu modyfikacjach nie mieści w swym niewielkim wnętrzu coraz liczniejszych parafian, będzie pełnił określone, specjalne zadania liturgiczne, dla których bliskość nowej świątyni jest również istotna. Dla realizacji tego zamierzenia należało więc znaleźć takie rozwiązanie architektoniczne bryły nowego kościoła i takie jego usytuowanie w stosunku do istniejących obiektów, aby umożliwić im wzajemną koegzystencję, dodając do melodii poetyckiego pejzażu kilka nowych, współbrzmiących akordów. ... Sterylność geometrii nowej formy sprawia, że architektura obiektu zabytkowego nabiera szczególnej wyrazistości i zyskuje na intensywności oddziaływania? 

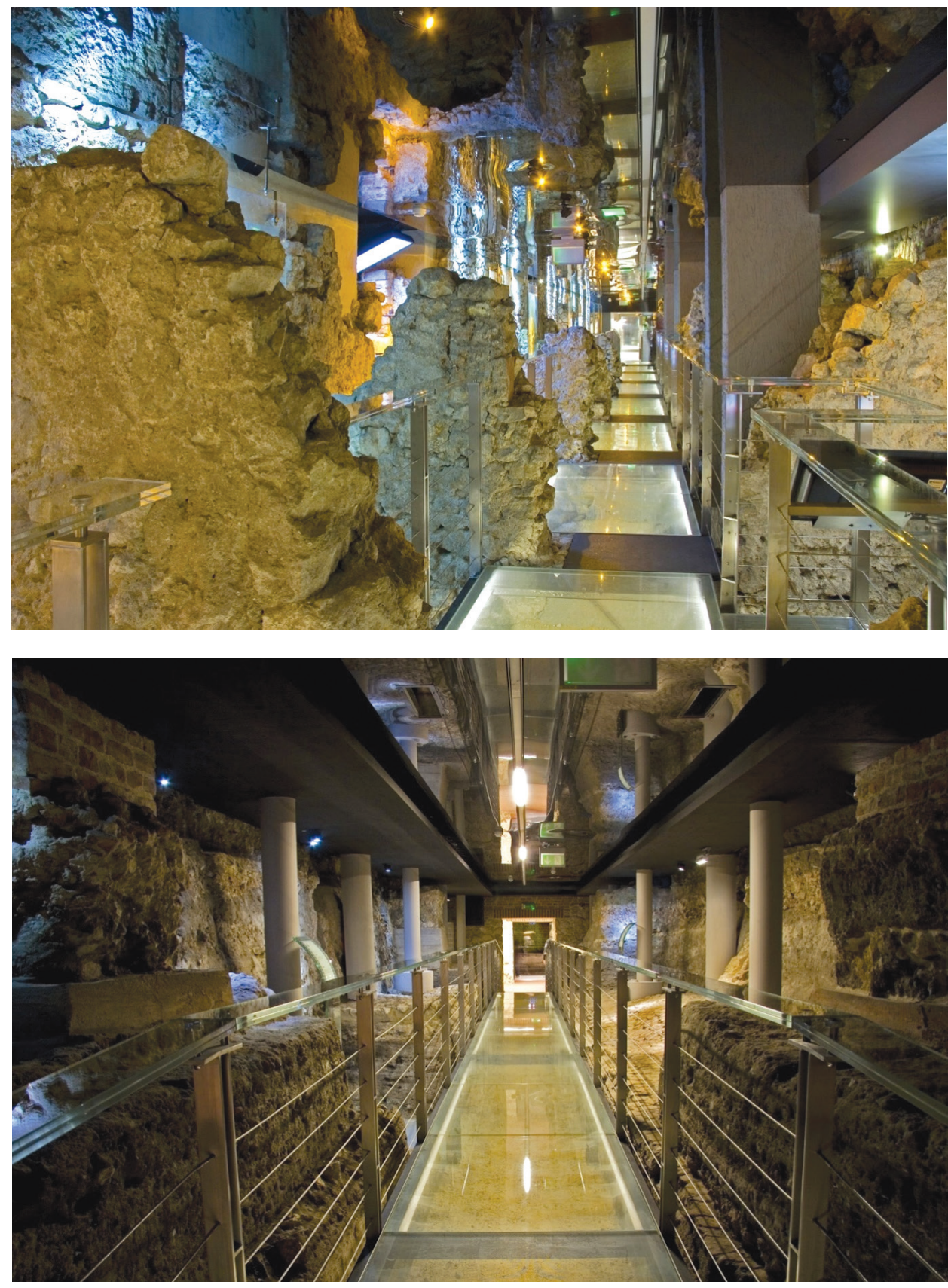

II. 1-2. Podziemne Muzeum Rynku Głównego w Krakowie (fot. P. Kotucha) III. 1-2. The underground Museum The Main Market Square in Kraków 

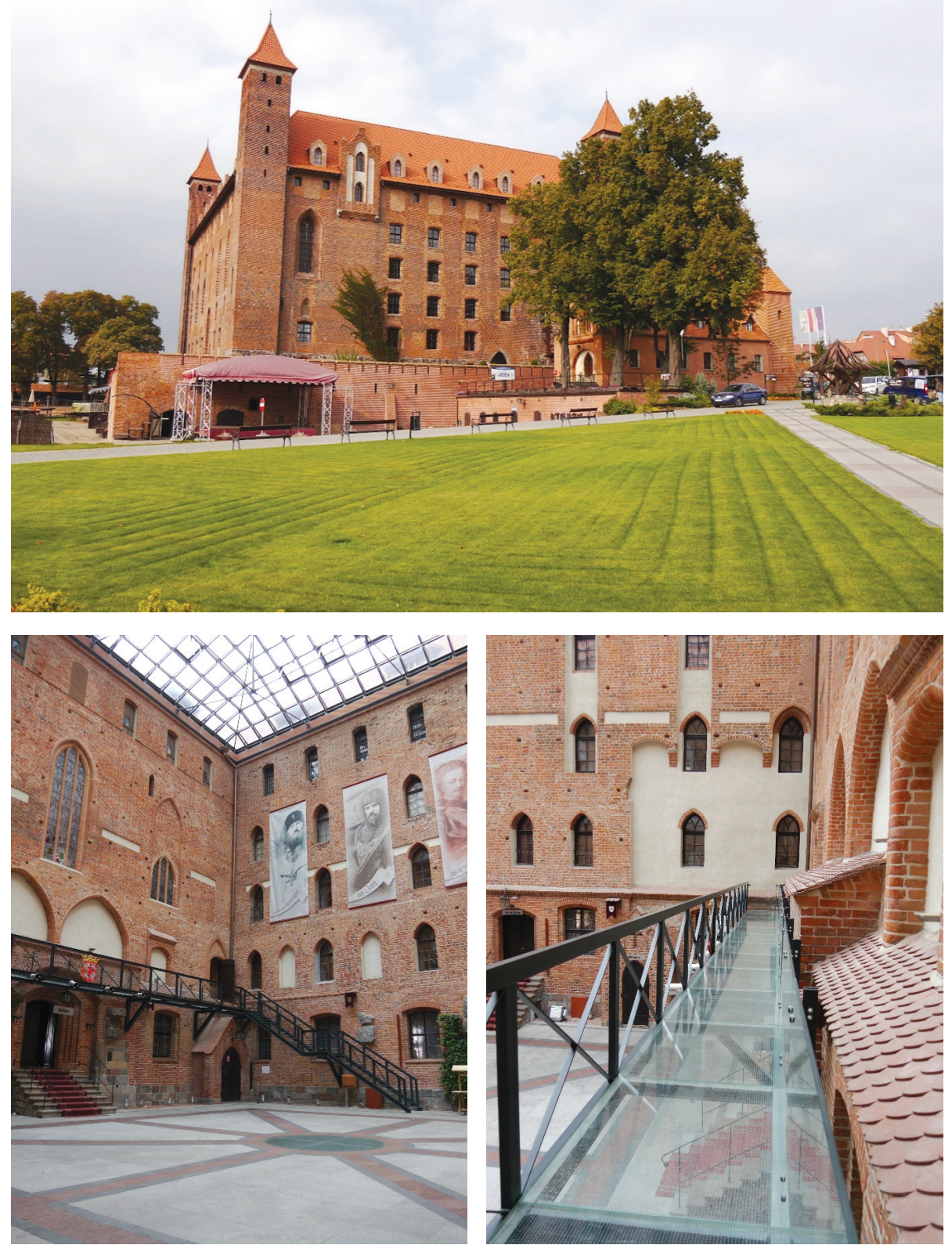

II. 3-5. Rewaloryzacja Zamku Krzyżackiego w Gniewie (fot. J. Gyurkovich)

III. 3-5. Regeneration of the Teutonic Castle in Gniew 

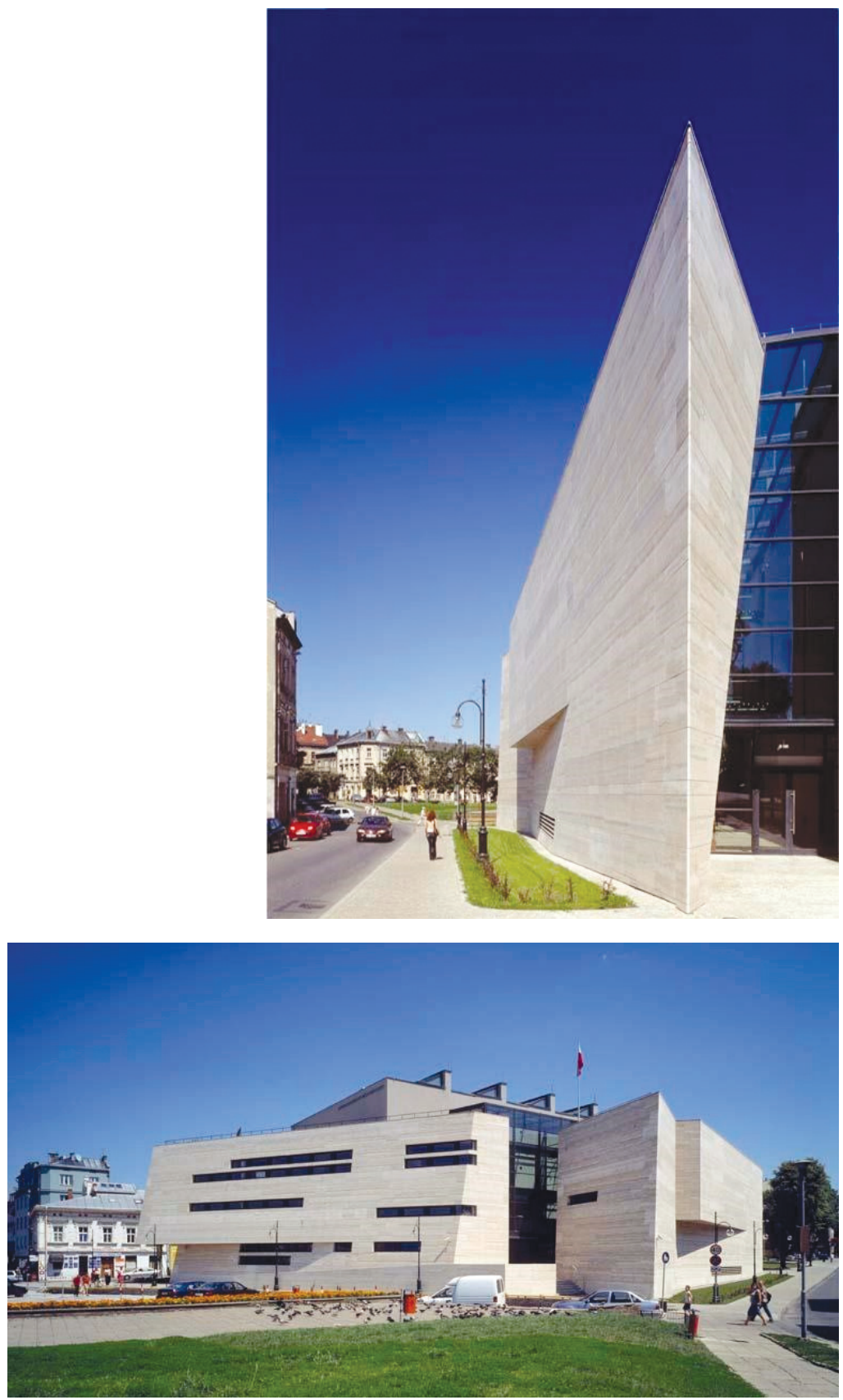

II. 6-7. Muzeum Narodowe Ziemi Przemyskiej (fot. archiwum KKM Kozień Architekci) III. 6-7. National Museum of Przemyśl 

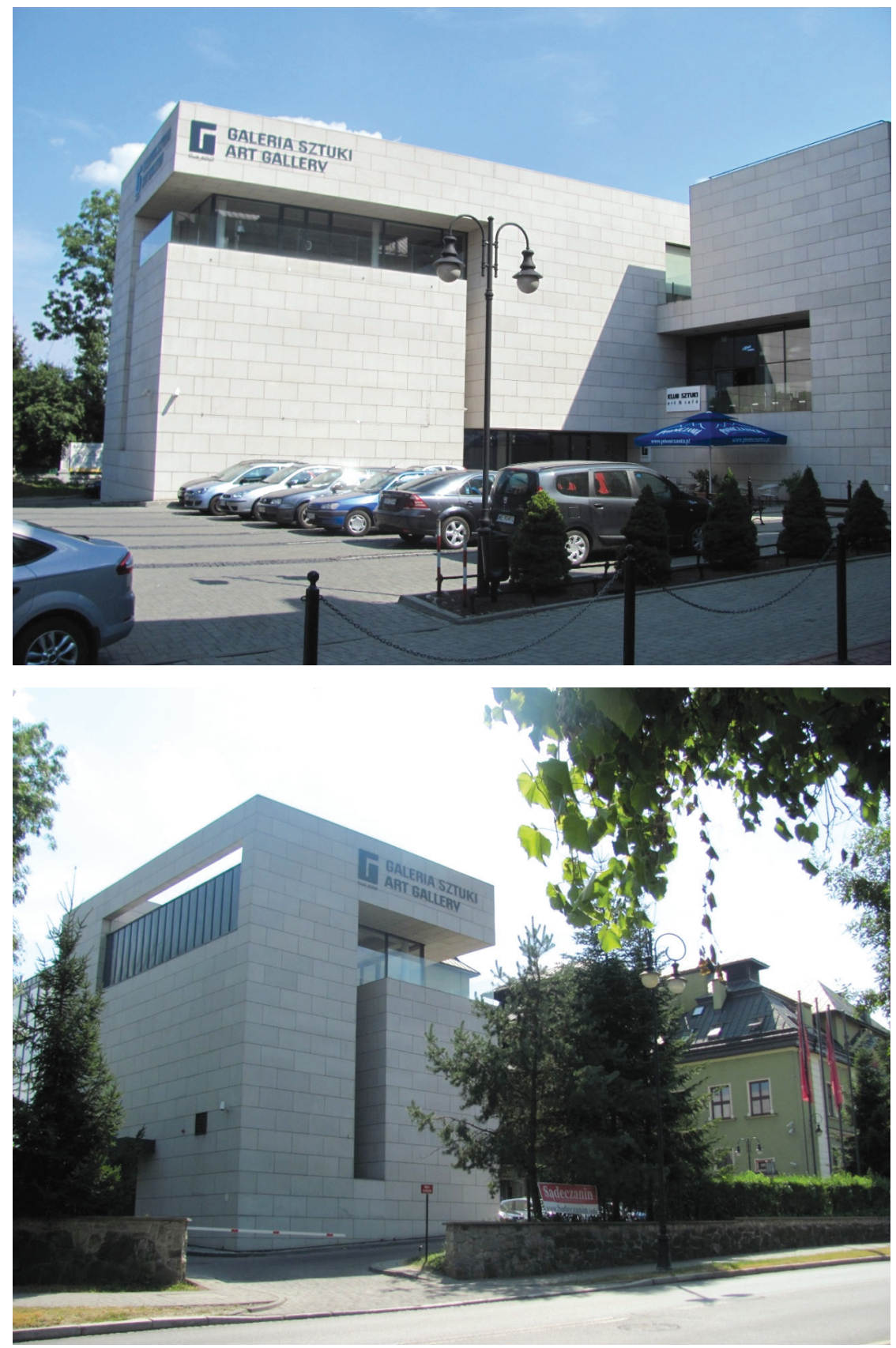

II. 8-9. Galeria Sztuki Współczesnej przy MCK „Sokół” w Nowym Sączu (fot. J. Gyurkovich) III. 8-9. Gallery of Modern Art at the MCK "Sokół" in Nowy Sącz 

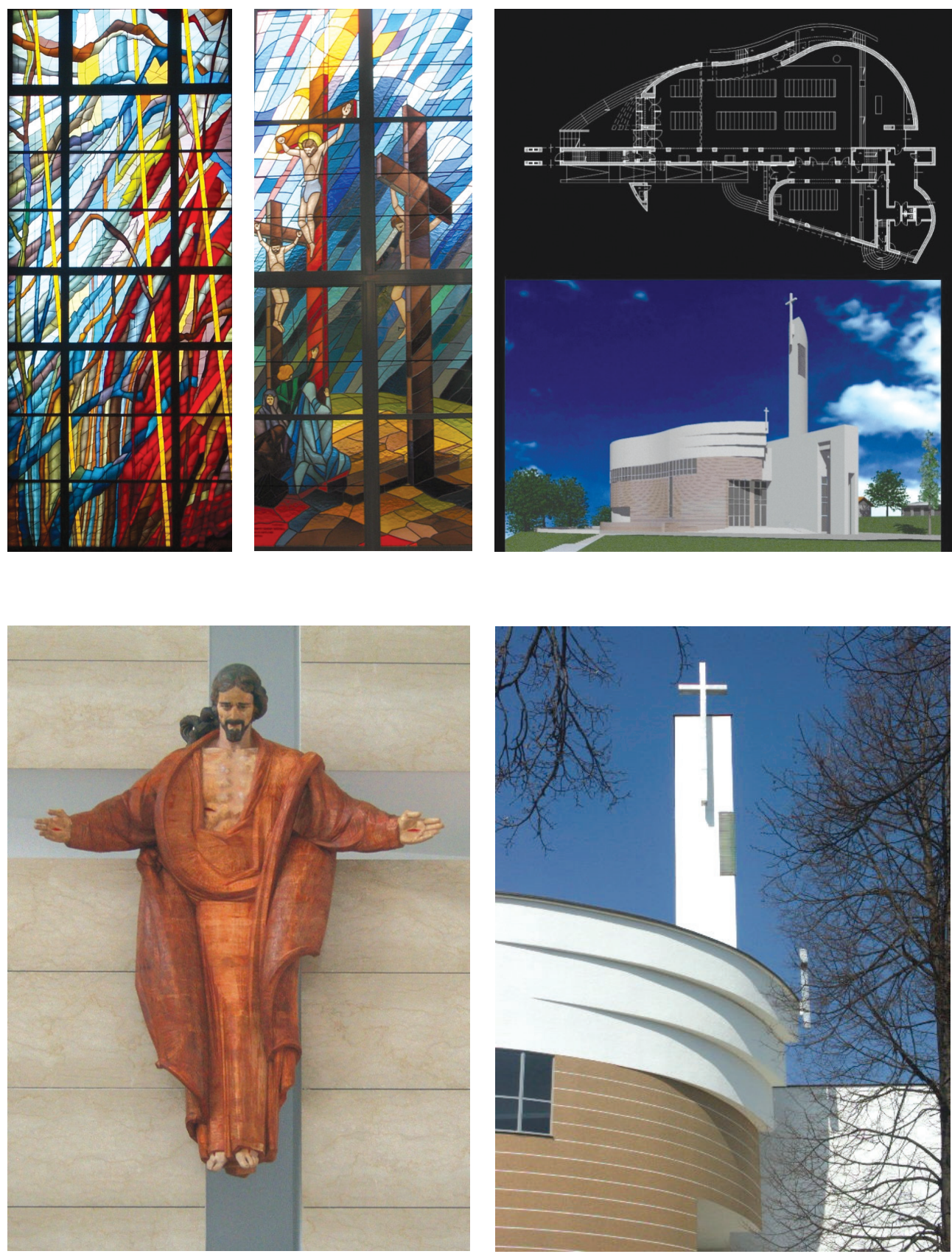

II. 10-14. Łęki Górne - kościół pw. Chrystusa Króla (fot. J. Gyurkovich) III. 10-14. Łęki Górne - Church of Christ the King 


\section{PRZYPISY}

1 Pełne prawa akademickie, a więc uprawnienia do nadawana stopni naukowych doktora habilitowanego w dyscyplinie naukowej architektura i urbanistyka mają także wydziały architektury Politechniki Gdańskiej, Warszawskiej i Wrocławskiej. Prawo do nadawania stopnia naukowego doktora w tej dyscyplinie mają dodatkowo wydziały architektury Politechniki Białostockiej, Łódzkiej, Poznańskiej i Śląskiej oraz Zachodniopomorskiego Uniwersytetu Technicznego w Szczecinie, https://polon.nauka.gov.pl/opi/aa/ck/stnauk/upr;jsessionid= 1D4F90CF856A973B9F716034328C1ADD.NwsProdB?execution=e1s1.

2 J. Gyurkovich, Misja i strategia Wydziału Architektury Politechniki Krakowskiej 2017-2020, http://arch.pk.edu.pl.

3 Uchwała nr 409 Rady Ministrów z dnia 7 lipca 1954 r. w sprawie utworzenia Politechniki Krakowskiej, [w:] Monitor Polski - Dziennik Urzędowy Polskiej Rzeczypospolitej Ludowej Nr A-68, Warszawa, dnia 21 lipca 1954.

4 J. Gyurkovich, Misja i strategia Wydziału Architektury Politechniki Krakowskiej 2017-2020, http://arch.pk.edu.pl.

5 Ibidem.

6 http://arch.pk.edu.pl/wydzial/o-wydziale/wspolpraca-miedzynarodowa/

7 A. Kadłuczka, Ortodoksyjna kreacja przestrzeni architektonicznej Podziemnego Muzeum Rynku Krakowskiego/Orthodox creation of architectonic space in the Underground Museum of the Market Square in Kraków, „Wiadomości Konserwatorskie”, Nr 28/2010, s. 15.

8 A. Kadłuczka, Zamek Krzyżacki w Gniewie. Przyczynek do jego chronologii i stratygrafii/ Castle of the Teutonic Order in Gniew: a comment on its chronology and stratigraphy, [w:] Historia i współczesność w architekturze i urbanistyce, Tom 1, Wydawnictwo Politechniki Krakowskiej, Kraków 2014, s. 5-30.

9 J. Gyurkovich, Poetyka sterylnej geometrii. Kompozycja formy mocnej w przestrzeni otwartej, [w:] Gyurkovich J., Znaczenie form charakterystycznych dla kształtowania i percepcji przestrzeni. Wybrane problemy kompozycji w architekturze i urbanistyce, Wydawnictwo Politechniki Krakowskiej, Kraków 1999, s. 154-162.

\section{BIBLIOGRAFIA}

Kadłuczka A., Podziemne Muzeum Rynku Głównego w Krakowie/Underground Museum The Main Market Square in Kraków, Wydawnictwo Politechniki Krakowskiej, Kraków 2010.

Uchwała nr 409 Rady Ministrów z dnia 7 lipca 1954 r. w sprawie utworzenia Politechniki Krakowskiej, [w:] Monitor Polski - Dziennik Urzędowy Polskiej Rzeczypospolitej Ludowej Nr A-68, Warszawa, dnia 21 lipca 1954. 
Kadłuczka A., Ortodoksyjna kreacja przestrzeni architektonicznej Podziemnego Muzeum Rynku Krakowskiego/Orthodox creation of architectonic space in the Underground Museum of the Market Square in Kraków, „Wiadomości Konserwatorskie”, Nr 28/2010, s. 15.

A. Kadłuczka, Zamek Krzyżacki w Gniewie. Przyczynek do jego chronologii i stratygrafii/ Castle of the Teutonic Order in Gniew: a comment on its chronology and stratigraphy, [w:] Historia i współczesność w architekturze i urbanistyce, Tom 1, Wydawnictwo Politechniki Krakowskiej, Kraków 2014, s. 5-30.

Gyurkovich J., Poetyka steryInej geometrii. Kompozycja formy mocnej w przestrzeni otwartej, [w:] Gyurkovich J., Znaczenie form charakterystycznych dla kształtowania i percepcji przestrzeni. Wybrane problemy kompozycji w architekturze i urbanistyce, Wydawnictwo Politechniki Krakowskiej, Kraków 1999, s. 154-162.

https://polon.nauka.gov.pl/opi/aa/ck/stnauk/upr;jsessionid=1D4F90CF856A973B9F716034 328C1ADD.NwsProdB?execution=e1s1

Gyurkovich J., Misja i strategia Wydziału Architektury Politechniki Krakowskiej 2017-2020, http://arch.pk.edu.pl

http://arch.pk.edu.pl/wydzial/o-wydziale/wspolpraca-miedzynarodowa/ 